\title{
Customer Relationship Management: A Tool for Customer Loyalty (A Case Study of Some Selected Hotels in Hawassa)
}

\author{
Andualem Walelign \\ Management Department, Jinka University, Ethiopia \\ Email: andualemwalelign26@gmail.com
}

\begin{abstract}
The main aim of this study was to investigate customer relationship management and customers' loyalty in Hawassa city selected hotels by applying CRM dimensions of bonding, communication, conflict handling, empathy, responsiveness and trust. Convenience sampling technique was used to collect data from customers of the selected hotels. In line with the objective, descriptive research methods were used to examine the customers' perceptions of CRM practices and future behavioral intentions. Inferential statistics were used to see the relationship between dependent and independent variables as well as to investigate cause and effect relationships. The key finding showed that there was a positive and significant effect of CRM dimensions of communication, conflict handling, empathy and trust on customer loyalty and selected hotel guests loyalty status shows that they were slightly intended to be loyal customer to the selected hotels. Bonding and responsiveness did not significantly affect guests' loyalty.
\end{abstract}

Keywords: Hotel sector, Customer relationship management, relationship marketing, perception, and customer loyalty

\section{Introduction}

Acquiring new customers can cost five to eight times more than satisfying and retaining current customers. Rather than focusing on transactional relationships companies recently recognized that the quality of relationships between buyers and sellers is much more important. This strategic direction refers to the concept of customer relationship management (Shvydenko, 2011). Customer Relationship Management (CRM) has a growing popularity and is becoming one of the hottest academic and practical topics in the business field. It is a new marketing campaign weapon which helps the business entity to stay competitive through serving internal and external customers efficiently (Shaon et al., 2015). Generally, CRM considered as an important marketing tools in establishing, developing, maintaining and optimizing of long-term mutually valuable relationship with customers in the service sectors including hotels (Angamuth, 2015).

Researchers suggested that creating partnerships with loyal customers require customer relationship management practices tailored through the coordination of internal and external programs. Organizational structure, culture and knowledge management considered as internal programs while interactive activities with customers like information exchange with the customer or involving him/her categorized under external program (Ghafari et al., 2011). From this point of view the present paper is interested on external programs of customer relationship management practices role on improving customer loyalty.

Different authors developed variety of customer relationship management variables to assess its relationship with customer loyalty. For instance, Kumari (2017), reviewed fourteen relationship marketing studies and revealed that trust, commitment, communication, conflict handling, empathy and bonding are considered as the most effective CRM dimensions. Finally, bonding, communication, conflict handling, empathy, responsiveness and trust are considered 
as an independent variable to investigate the customer relationship management influence on customer loyalty in Hawassa city selected hotels.

In today's constantly changing business environment, to be market focused and forming strong relationships with customers is more important than any other time in the past (Wijenayaka et al., 2015). The studies carried out in many countries revealed that factors related to key constructs of CRM dimensions have significant role on customer satisfaction and loyalty of customers (e.g. Avazzadeh, 2015; Lin Chen, 2012; Ujakpa \& Arora, 2015).

Various hotel industry investigations revealed that employees are important asset of the hotel. To build memorable relationships with customers, employees shall have technical knowhow concerning how to treat guests, respond to their needs, concerns and complains maintain good rapport and provide an enjoyable experience (Kangu 2017; Mubiri 2016). Lack of sufficient and competent professionals, lack of essential researches and professional support to provide essential input for modernizing the sector are considered as the major problems which manifested the Ethiopian hotel industry (Megersa, 2016).

CRM can be considered as the best strategies and practices for hotels in order to ensure longterm business survival since there exist various contact points which are known as 'touch points' in CRM language that necessitate the implementation of CRM strategic tools in hotel industry (Naveed, 2012). Hotels that don't implement CRM in their marketing strategy have struggled to yield better performance and always operate on a downward trend (Madhovi and Dhliwayo, 2017). As a result, the hotels should optimize communications with their customers to ensure profitable long-term relationships.

In addition to this, despite the existence of quite of opportunity for spreading the literature about CRM regarding the hotel industry, very little consideration has been given to the CRM scopes in the hotel industry (Kanchan \& Sharma, 2015). Most studies conducted on CRM were based on financial service industries such as banking, insurance services and the telecommunication services. Finally, to the researcher knowledge, there is no customer relationship management encompassing studies has been done on Hawassa town Hotel industry. Therefore in addition to the above stated theoretical gaps, lack of sufficient research from customer perspectives of CRM strategies that is conducted on Hawassa city hotel sector is the major gap of the study. Therefore, the aim of the study is to survey CRM role for customer loyalty of the selected hotels in Hawassa city. The objective is (1) to explore the perception of customers towards the customer relationship management practices of the selected hotels; (2) to assess the future behavioral intention of customers/guests in the context of Hawassa town selected hotels; (3) to investigate the relationship of perceived customer relationship management practices with customer loyalty; (4) to identify the relative influence of each customer relationship management dimensions on customer loyalty.

\section{Literature Review}

According to Angamuthu (2015), Customer Relationship Management (CRM) is the strongest and the most efficient approach of maintaining and creating close relationships with customers in the service sectors including hotels. The literature review exposed that there exist a close, direct and comprehensive relationship between the concepts of customer relationship management and relationship marketing. Both concepts borrow from one another and follow 
the same trajectory using similar frameworks. The close relationship between these two concepts arises from the fact that the literature on relationship marketing forms the conceptual underpinning of customer relationship management. The study conceptual work considered the works of Kumari, (2017), Wasfi and Kostenko (2013), Shaon et al., (2015) while constructing the study conceptual frame work.

CRM dimensions

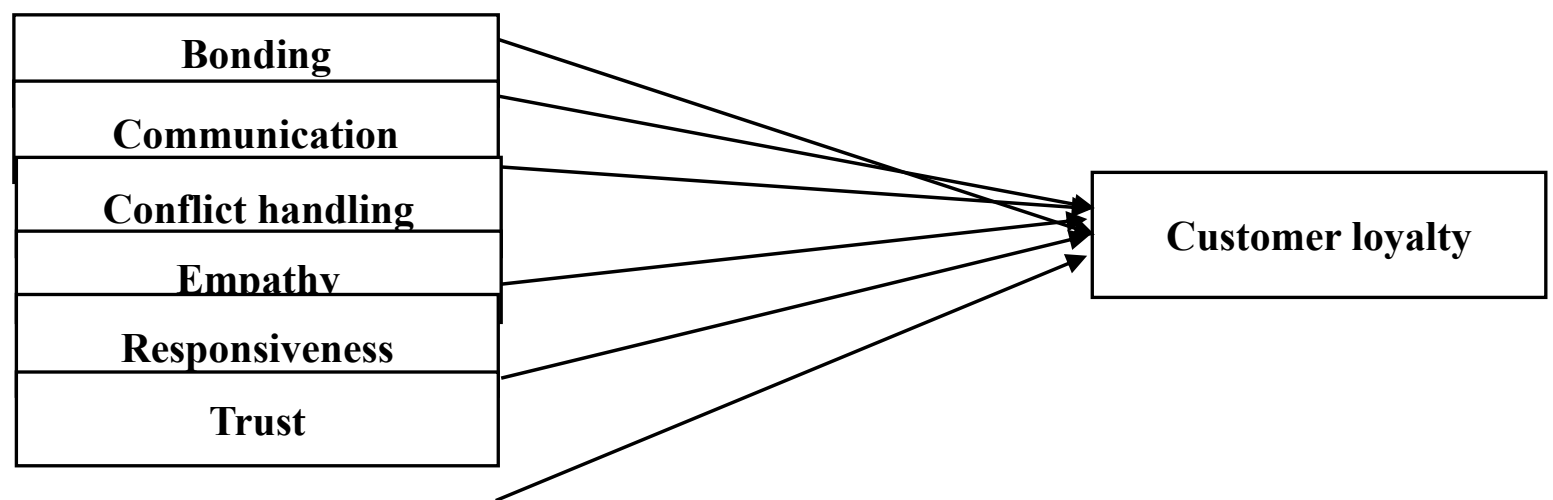

Figure 1. (Conceptual framework of the study adapted from reviewed literatures, 2018)

\section{Research Method}

The study was conducted in selected hotels of Hawassa city. Descriptive type of research design was adopted for this study for the realization of intended objectives. The researcher also employed the survey method. Questionnaire was used to collect relevant data. The literature reviewed was the major input to develop the data collection instrument. The research is again cross sectional type since the study was conducted by one time data collection and analysis. Both primary and secondary data's were used for the study in order to come up with concrete finding.

The researcher utilized a purposive sampling technique to select the hotel categories to be included in this study. Accordingly the targeted hotels were those under four and three star categories due to better service quality expectation relative to the remaining hotel categories and for that they are frequently used by the targeted visitors (Dubois et al., 2005). Based on the consent of hotelier's two hotels from each star level namely, Ker Awud international hotel, Lewi hotel and resort, Oasis international hotel and Hawassa Pinna hotel were included in the study. The researcher also considered the selected hotels proximity to the center of the town as well as transaction methods of hotels such as the practice of online booking or reservation system and payment methods which are critical for maintaining relationship with the whole world.

The sample size for the study determined based on the sample frame and by using calculated Krejcie and Morgan table to determine the sample size with 95 percent confidence level and 5 percent confidence interval. In this way, an initial sample size of 351 determined for the calculated target population of 4,000 guests. Finally, by giving 10 percent grant for possible risks associated with low response rate the researcher distributed 390 questionnaires to the selected hotels proportionately to the capacity of the selected hotels (see table 2.1). Out of the total questionnaire distributed to the selected hotels, 349 questionnaires were returned. From these 25 questionnaires were not filled properly as per the instructions. From this, one can understand that the analysis was done with 324 valid responses. 
Table 1. Distribution of Expected visitors per month during data collection period

\begin{tabular}{|l|l|l|l|l|}
\hline Hotels & Star level & Expected guest & No. of beds & Sample size \\
\hline $\begin{array}{l}\text { Ker-Awud } \\
\text { International Hotel }\end{array}$ & $* * * *$ & 900 & 50 & 88 \\
\hline Lewi Hotel \& Resort & $* * * *$ & 1,850 & 58 & 180 \\
\hline $\begin{array}{l}\text { Oasis international } \\
\text { hotel }\end{array}$ & $* * *$ & 650 & 39 & 63 \\
\hline Pinna hotel & $* * *$ & 600 & 32 & 59 \\
\hline Total & & $\mathbf{4 , 0 0 0}$ & $\mathbf{1 7 9}$ & $\mathbf{3 9 0}$ \\
\hline
\end{tabular}

Source; selected hotels report; computed by the researcher, 2018

The unit of analysis for the study was the individual customer. That is, the guests being the direct recipient of services delivered by the selected hotels. The collected data analyzed and processed both qualitatively and quantitatively by using descriptive data analysis techniques. To show the relative influence and the degree of relationship among independent variables and dependent variables, Pearson's correlation coefficient and multiple linear regression model were used by the researcher. Regression in the form of mathematical equation, written as,

$\mathrm{Yi}=\beta_{0}+\beta_{1} \mathrm{X}_{1}+\beta_{2} \mathrm{X}_{2}+\beta_{3} \mathrm{X}_{3}+\beta_{4} \mathrm{X}_{4}+\beta_{5} \mathrm{X}_{5}+\beta_{6} \mathrm{X}_{6}+\mathrm{e}$

Where, $\mathrm{Yi}$, is the dependent variable representing customer loyalty and $\mathrm{X}_{1}, \mathrm{X}_{2}, \mathrm{X}_{3}, \mathrm{X}_{4}, \mathrm{X}_{5}$ and $\mathrm{X}_{6}$ are the explanatory variables representing perceived bonding, communication, conflict handling, empathy, responsiveness and trust respectively. $\beta_{0}$, is the constant (the intercept of the model), $\beta_{\text {is }}$ are regression coefficients of Xis variables while e is the error term.

\section{Findings and Discussions}

\subsection{Analysis of constructs}

Descriptive statistics (mean and standard deviations) of the respondent scores were computed with the aim of providing an overall view of the respondents' perception concerning each items of customer relationship management and customer loyalty listed in the Likert scale.

Table 2. Summary of Mean Scores and Standard Deviation of Constructs

\begin{tabular}{|l|l|l|l|l|}
\hline Constructs & No. of items & N & Mean & Std. Deviation \\
\hline Bonding & 5 & 324 & 3.43 & 0.945 \\
\hline Communication & 4 & 324 & 3.71 & 1.061 \\
\hline Conflict Handling & 4 & 324 & 3.66 & 0.995 \\
\hline Empathy & 4 & 324 & 3.74 & 1.064 \\
\hline
\end{tabular}

Source: Own Survey, 2018 


\begin{tabular}{|l|l|l|l|l|}
\hline Responsiveness & 4 & 324 & 3.73 & 0.947 \\
\hline Trust & 5 & 324 & 3.63 & 0.953 \\
\hline Customer loyalty & 5 & 324 & 3.57 & 0.901 \\
\hline
\end{tabular}

As indicated in table 2, empathy has the highest score of 3.74 followed by responsiveness with a score of 3.73. Communication was ranked third with a mean score of 3.71. This implies that the selected hotel guests were impressed with the overall communication process of the hotels. According to Rao and Sahu (2013), effective communication among divisions in the hotel is one of the main factors that contribute to customer satisfaction which in turn influence future behavioral intention or loyalty status of hotel guests. The least perceived dimension according to the finding was bonding with a mean score of 3.43. The customers/guests of the selected hotels rated this dimension lowly in comparison to other dimensions and they perceive that the hotels should do more in terms of establishing a long term relationship with its customers. The finding further indicates that empathy is expected to play a key role in determining the loyalty of customers whereas bonding expected to play a smaller role as depicted by the mean composite score of 3.43. High levels of empathetic customer-employee interaction may result in loyalty and positive word of mouth behavior (Nekudova, 2014).

The standard deviations of CRM dimensions range from 0.945 to 1.064 . The least standard deviation of 0.945 was obtained for bonding. This means the respondents (irrespective of the selected hotels) have the most related views as far as bonding as a component of the selected hotels CRM practices are concerned. The highest standard deviation of 1.064 was obtained for empathy. This means the respondents have more diverse views with regards to the issue of empathy (perhaps, empathy depends on the type of the selected hotels).

Table 3.1 further shows that mean score of hotel guests' response regarding customer loyalty items. The overall mean score of 3.57 with standard deviation of 0.901 indicates that customers/guests of the selected hotels slightly intended to become loyal customer. The finding exposed that the need of implementing variety of loyalty programs to improve the loyalty level of hotel guests. A loyalty or membership program can become a more reliable tool for hospitality business to learn more about their customers' behaviors and future intentions to purchase (Kim et al., 2016).

\subsection{Correlation analysis}

Correlation is a statistical measurement of the relationship between two variables. The following general guidelines indicate a quick way of interpreting the value of correlation coefficient: -0.9 to -1.0 or 1.0 to 0.9 very strong; -0.9 to 0.7 or 0.7 to 0.9 strong; -0.7 to -0.4 or 0.4 to 0.7 moderate; -0.4 to -0.2 or 0.2 to 0.4 weak, low correlation and -0.2 to 0.0 or 0.0 to 0.2 very weak to negligible negative/positive correlation (Rahman et al., 2014). Accordingly, Pearson's correlation coefficients statistical method was used to determine the relationship between CRM practices of the selected hotels and customers' loyalty (see table 3 ). 
Table 3. Correlations between CRM and Customer Loyalty

**Correlation is significant at the 0.01 level (2-tailed).

\begin{tabular}{|l|l|l|}
\hline Customer Relationship Management & Customer Loyalty \\
\hline \multirow{4}{*}{ Bonding } & Pearson correlation & $0.338^{* *}$ \\
\cline { 2 - 3 } & Sig.(2-tailed) & 0.000 \\
\cline { 2 - 3 } & $\mathrm{N}=$ & 324 \\
\hline \multirow{4}{*}{ Communication } & Pearson correlation & $0.680^{* *}$ \\
\cline { 2 - 3 } & Sig.(2-tailed) & 0.000 \\
\cline { 2 - 3 } & $\mathrm{N}=$ & 324 \\
\hline \multirow{5}{*}{ Empathy } & Pearson correlation & $0.736^{* *}$ \\
\cline { 2 - 3 } & Sig.(2-tailed) & 0.000 \\
\cline { 2 - 3 } & $\mathrm{N}=$ & 324 \\
\hline \multirow{4}{*}{ Responsiveness } & Pearson correlation & $0.691^{* *}$ \\
\cline { 2 - 3 } & Sig.(2-tailed) & 0.000 \\
\cline { 2 - 3 } & $\mathrm{N}=$ & 324 \\
\cline { 2 - 3 } & Pearson correlation & $0.510^{* *}$ \\
\cline { 2 - 3 } & Sig.(2-tailed) & 0.000 \\
\cline { 2 - 3 } & $\mathrm{N}=$ & 324 \\
\cline { 2 - 3 } & Pearson correlation & $0.726^{* *}$ \\
\cline { 2 - 3 } & Sig.(2-tailed) & 0.000 \\
\cline { 2 - 3 } & $\mathrm{N}=$ & 324 \\
\hline Customer Loyalty & Pearson correlation & 1 \\
\cline { 2 - 3 } & Sig.(2-tailed) & 0.000 \\
\cline { 2 - 3 } & $\mathrm{N}=$ & 324 \\
\hline
\end{tabular}

Source: Own Survey, 2018

The results of correlation analysis shows that all the independent variables are positively and significantly correlated with the dependent variable (customer loyalty). The results reflected that CRM practices of the selected hotels conflict handling mechanism was strongly associated with guests' loyalty level. These relationships were both theoretically and logically acceptable as conflict handling in terms of showing sincere interest in solving customer problem to meet the guests best interest can contribute towards better service perceptions and favorable future behavioral intention. This idea is reinforced by the belief that complaining customers' embodies the most loyal ones, and they are utmost expected to repeat the purchase (Wasfi and Kostenko, 2014).

Relatively weak association was observed between bonding dimension and customer loyalty. The results indicate that the need of cultivating CRM aspects related with bonding dimensions since strong bonds between the seller and the buyer limits potential conflicts between the two parties, develop and enhance customer loyalty which in-turn impacts directly in feelings of affection and a sense of belonging to the service provider (Ghani et al., 2016).

\subsection{Multiple Regression analysis result of CRM and Customer Loyalty}

A Multiple Linear Regression analysis was conducted to investigate the relative influence of each CRM dimension on customer loyalty. The results are presented in table 4 and 5 below.

Table 4. Model Summary 


\begin{tabular}{|l|l|l|l|l|l|}
\hline Model & $\mathrm{R}$ & R Square & $\begin{array}{l}\text { Adjusted } \\
\text { Square }\end{array}$ & $\begin{array}{l}\mathrm{R} \\
\text { Std. Error of the } \\
\text { Estimate }\end{array}$ & Durbin-Watson \\
\hline 1 & $.822^{\mathrm{a}}$ & .676 & .670 & 1.63918 & 1.939 \\
\hline
\end{tabular}

a. Predictors: (Constant), trust, bond, respo, conflict, commu, empathy

b. Dependent Variable: loyalty

The magnitude of the adjusted R Square is 0.670 . This means that 67 percent of the dependent variable (customer loyalty) can be explained or influenced by the independent variables of CRM dimensions, while the remaining 33 percent is explained by other causes. For instance, the study by Vuuren et al., (2012), customer satisfaction, trust, commitment and supplier image influence customer loyalty.

Table 5. Coefficient

\begin{tabular}{|c|c|c|c|c|c|c|c|}
\hline \multirow[t]{2}{*}{ Model } & \multicolumn{2}{|c|}{$\begin{array}{l}\text { Unstandardized } \\
\text { Coefficients }\end{array}$} & \multirow{2}{*}{\begin{tabular}{|l} 
Standardized \\
Coefficients
\end{tabular}} & \multirow[t]{2}{*}{$T$} & \multirow[t]{2}{*}{ Sig. } & \multicolumn{2}{|c|}{$\begin{array}{l}\text { Collinearity } \\
\text { Statistics }\end{array}$} \\
\hline & B & Std. Error & & & & Tolerance & VIF \\
\hline (Constant) & 2.144 & .593 & & 3.616 & .000 & & \\
\hline Bond & .034 & .033 & .036 & 1.005 & .316 & .796 & 1.257 \\
\hline Commu & .207 & .054 & .186 & 3.806 & .000 & .428 & 2.336 \\
\hline Conflict & .392 & .052 & .351 & 7.485 & .000 & .465 & 2.148 \\
\hline Empathy & .142 & .058 & .130 & 2.430 & .016 & .357 & 2.804 \\
\hline Respo & .019 & .053 & .016 & .367 & .714 & .563 & 1.776 \\
\hline Trust & .216 & .046 & .251 & 4.751 & .000 & .367 & 2.728 \\
\hline
\end{tabular}

a. Dependent Variable: Loyalty

Source: Own Survey, 2018

On the basis of the analysis of multiple regression result, it can be said that the relationship between the independent variables (viz. communication, conflict handling, empathy, and trust) and dependent variable (i.e. customer loyalty) is significant at 5 percent significance level. Unstandardized beta coefficients (also known as rate of change) indicated how much the dependent variable varies with an independent variable, when all other independent variables are held constant. Standardized regression coefficients, were used to determine the relative importance of the CRM dimensions in predicting customer loyalty. The beta coefficients indicated that how and to what extent the CRM dimensions influence customers' loyalty. On the basis of the result of multiple linear regression analysis result, multiple regression model 
can be written as follows;

$\mathrm{Yi}=2.144+0.186 \mathrm{X}_{1}+0.351 \mathrm{X}_{2}+0.130 \mathrm{X}_{3}++0.251 \mathrm{X}_{4}+0.05$

Where, Yi, is the dependent variable (customer loyalty),

The value 2.144 is the constant (the value of $y$ when the value of all independent variables are 0 ), whereas, $X_{1}, X_{2}, X_{3}$, and $X_{4}$ refers perceived communication, conflict handling, empathy, and trust. Finally, the researcher set its confidence level at 95 percent with 5 percent $(0.05)$ error term.

As indicated from the regression result, the researcher identified that not all of the proposed CRM dimensions have positive and significant influence on customer loyalty. Out of the six CRM dimensions four dimensions (communication, conflict handling, empathy and trust) have positive and significant influence on customer loyalty. Conflict handling with its beta coefficient value of 0.351 has emerged as the most important CRM construct in predicting customer loyalty. Bonding and responsiveness dimension of CRM have no significant influence on customer loyalty. This postulates that increase in CRM practices of items related to bonding and responsiveness dimension couldn't necessarily leads to increase in customer loyalty.

Finally, one can conclude that the findings of this study comply with the results of earlier studies. These findings provide significant support for the communication, conflict handling, empathy and trust literatures which advocates that the variables have positive and significant influence up on customer loyalty. For instance, the study conducted by Kanyan et al., (2015), revealed that conflict handling, communication and trust are positively associated to customer loyalty. Furthermore, the study found that conflict handling is the most important dimension that affects customer loyalty with beta coefficient of $(\beta=0.357)$. Similarly, a subsequent multiple regression analysis result of Abdullah and Kanyan (2013) reveals the positive and significant influence of empathy on customer loyalty.

The results failed to confirm the significant influence of perceived customer relationship management dimensions of bonding and responsiveness on customers loyalty as found in some earlier researches. For instance, the study by Khuong et al., (2015) revealed the insignificant effect of responsiveness to customers loyalty. Similarly, the study by Anabila (2010) found that the slight positive influence of bonding on customers loyalty. However, the study revealed that the influence of bonding was insignificant $(\mathrm{P}=0.245>0.05, \beta=0.077)$.

\section{Conclusion}

This study revealed that based on the customers' view, customer relationship management factors have been taken seriously in the selected three star and four star hotels. The study also indicates that customers are highly satisfied by the perceived empathy dimension of the selected hotels. The least performance was obtained from the mean score of bonding dimension. As indicated by different relationship management related literatures, bonding dimension was one of the most important factors influencing customer loyalty. But, customers do not particularly feel so much bonded with hotels which therefore cause for a managerial look being taken at that. This comes in the form of keeping in touch with customers constantly and building close co-operation with the firm.

The mean score value also indicates that customers were satisfied with the hotels overall relationship management efforts but not necessarily agree that the hotel ensures high level of customer loyalty. Therefore, managers must carefully understand the value perceived by 
different market segments. Customers may sometimes refrain from purchasing when price is perceived to be too high, while some became suspicious of quality when price is too low. In summary, understanding the relationship among enhancing high quality customer relationship and loyalty will help managers make decision and plan their strategies in the competitive hospitality market environment. The study concluded that customer relationship management practice play significant role to enrich customer loyalty. Four CRM dimensions have the greatest predictive power on customer loyalty and these are conflict handling, trust, communication, and empathy. An increase in these CRM variables results in an increase in the levels of customer loyalty.

Lack of sufficient research conducted on the relationship management aspects of hotel services in Ethiopia was the major limitation of the study. This study can provide insights for further research in service marketing area. First of all, the findings of this study show that the implemented CRM dimensions are incomplete and that further investigations can uncover more dimensions in different service context. The results of this study also may not have been representative of the whole population. The study was limited to four hotels in Hawassa town; a replication can be undertaken with a more hotels to compare the results in different categories of hotels. Furthermore, as this research has been carried out with limited resources, total of 324 valid respondents have taken part, however for the future endeavors larger samples would be advisable.

Moreover, given that the results of this study are generalized to the whole population irrespective of socio-cultural differences, findings could be different when socio-cultural background differences are considered since relationship marketing means different things in different cultures (Husnain \& Akhtar, 2015). This suggests a need for more cross-cultural research. Finally, through using different methodologies or techniques, especially which is not used by this study for example, qualitative methods such as focus group and personal interview and the like will be used in future research to gain further insights about the association between the dimensions of perceived customer relationship management practices with customer loyalty.

\section{References}

Ali, F. (2015). Service quality as a determinant of customer satisfaction and resulting behavioral intentions: A SEM approach towards Malaysian resort hotels. Original scientific paper, 63(1).

Anabila, P. (2010). Customer relationship management (CRM): A study of Ghana's banking industry. Unpublished PhD Thesis submitted to University of Ghana, Legon.

Angamuthu, B. (2015). Impact of customer relationship management on customer satisfaction and its role towards customer loyalty and retention practices in the hotel sector. Journal of Management Research, 7(1), 43 - 52.

Avazzadeh, E. (2015). Investigation the effect of customer relationship management on customer's loyalty and satisfaction (case study: Shiraz city Refah chain stores). International Journal of Advanced and Applied Sciences, 2(2), 11-15.

Dubois, B., Laurent, G., \& Czellar, S. (2005). Consumer segments based on attitudes toward luxury: Empirical evidence from twenty countries. Marketing Letters, 16(2), 115-128.

Eshetu, E. (2014). The influence of customer relationship marketing to improve customer loyalty a case of commercial Bank of Ethiopia (Addis Ababa). Unpublished thesis. 
Etikan, I., \& Bala, K. (2017). Sampling and Sampling Methods. Biom Biostat International Journal, 5(6).

Ghafari, P., Karjalian, R., \& Mashayekhnia, A. (2011). Studying the relationship between different dimensions of CRM and innovation capabilities in Melli bank of Iran. World academy of science, engineering and technology.

Ghani, M., Othman, A., Ibrahim, N., \& Ismail, W. (2016). Relationship marketing practices and effects on marketing effectiveness: An empirical insight from the hotel industry. International Review of Management and Marketing, 6(4).

Husnain, M., \& Akhtar, M. (2015). Relationship marketing and customer loyalty: Evidence from banking sector in Pakistan. Global Journal of Management and Business Research: E Marketing, 15(10).

Kanchan \& Sharma, A. (2015). Application of customer relationship management (CRM) practices in hotel industries: A review. International Journal of BRIC Business Research, 4, $(1 / 2 / 3)$.

Kangu, M. (2017). The role of customer relationship management dimensions on customer loyalty in the hotel industry in Kenya. Unpublished $\mathrm{PhD}$ thesis.

Kanyan, A., Andrew, J. V., Ali, J.K., \& Beti, M. (2015). Building customer relationship for gaining customer loyalty in the pharmaceutical industry. Journal of Advanced Management Science, 3(4), 319-322.

Khuong, M., Ngan, P., \& Nguyen Thi Minh Phuong, N.T. (2015). Factors of affecting guests' satisfaction and their loyalty - A study of luxury hotels in Ho Chi Minh City, Vietnam, International Journal of Innovation, Management and Technology, 6(3), 186-190.

Kim, M., Vogt, C., \& Knutson, B. (2016). Evidence of member hotel programs boosting loyalty. Journal of Tourism and Hospitality Management, 4(2), 49-63.

Kumari, C.M. (2017). Relationship marketing dimensions on customer satisfaction and customer loyalty - A review. Journal of Advance Research in Business, Management and Accounting, 3(9).

Lin Chen, C. (2012). Conceptualizing customer relationship management and its impact on customer lifetime value. Unpublished $\mathrm{PhD}$ thesis.

Madhovi, P. G., \& Dhliwayo, S. (2017). The relationship between customer relationship management (CRM) and performance in the hotel industry. African Journal of Hospitality, Tourism and Leisure, 6(1), 1 - 13.

Megersa, H. (2016). A historical survey of hotel services in Bahir Dar Town since 1930s: Challenges and prospects. African Journal of History and Culture, 8(2), 9-14.

Mubiri, J. (2016). Customer satisfaction in hotel services. Case-Lake Kivu Serena Hotel. Unpublished Bachelor's thesis.

Naveed, U. (2012). Customer relationship management in hospitality sector. Journal of Good Governance and Sustainable Development, 1(1), 40-47.

Nekudova, J. (2014). A comparative analysis of customer's perception of hotel restaurants in Great Britain and New Zealand (relationship marketing study). 
Rahman, H., Redwanuzzaman, Ul-Hasan, M., \& Rahman.S (2014). Factors affecting customer satisfaction on grameenphone users in Bangladesh. Global Journal of Management and Business Research: E Marketing, 14(3), 57-66.

Rao, P. S., \& Sahu, P.C. (2013). Impact of service quality on customer satisfaction in hotel industry. Journal of Humanities and Social Science (IOSR-JHSS), 18(5), 39-44.

Shaon, K, S. M., \& Rahman, H. (2015). A theoretical review of CRM effects on customer satisfaction and loyalty. Prague economic papers, 4(1), 23-36.

Shvydenko, O. (2011). Influence of customer relationship management (CRM) on consumer loyalty. Unpublished MSc Thesis.

Ujakpa, M., \& Arora, R. (2015). Customer relationship marketing practices and its effect on customer satisfaction in commercial banks: The case of Energy Bank Ghana Ltd. International Journal of Knowledge, Innovation and Entrepreneurship, 3(2), 43 - 63.

Vuuren, V., Lombard, R., \& Tonder, V. (2012). The relationship between selected variables and customer loyalty within an optometric practice environment. Acta Commercii, 94 -106.

Wasfi, H., \& Kostenko, O. (2014). The impact of complaint management on customer retention. Unpublished thesis Final assignment for Master Degree in Business Administration.

Wijenayaka, H., Perera, D., \& Sanjeewa, W. (2015). Assessing customer relationship management strategies for creating customer loyalty in insurance industry. Proceedings of 8th International Research Conference, 204-208.

\section{Copyrights}

Copyright for this article is retained by the author(s), with first publication rights granted to the journal.

This is an open-access article distributed under the terms and conditions of the Creative Commons Attribution license (http://creativecommons.org/licenses/by/4.0/) 